\title{
Timing the multiple cell death pathways initiated by Rose Bengal acetate photodynamic therapy
}

\author{
E Panzarini ${ }^{1}, \mathrm{~V}$ Inguscio ${ }^{1}$ and L Dini ${ }^{*, 1}$
}

Rose Bengal acetate photodynamic therapy (RBAc-PDT) induced multiple cell death pathways in HeLa cells through ROS and ER stress. Indeed, apoptosis was the first preferred mechanism of death, and it was triggered by at least four different pathways, whose independent temporal activation ensures cell killing when one or several of the pathways are inactivated. Apoptosis occurred as early as $1 \mathrm{~h}$ after PDT through activation of intrinsic pathways, followed by activation of extrinsic, caspase-12dependent and caspase-independent pathways, and by autophagy. The onset of the different apoptotic pathways and autophagy, that in our system had a pro-death role, was timed by determining the levels of caspases 9, 8, 3 and 12; Bcl-2 family; Hsp70; LC3B; GRP78 and phospho-elF2 $\alpha$ proteins. Interestingly, inhibition of one pathway, that is, caspase-9 (Z-LEHD-FMK), caspase-8 (Z-IETD-FMK), pan-caspases (Z-VAD-FMK), autophagy (3-MA) and necrosis (Nec-1), did not impair the activation of the others, suggesting that the independent onset of the different apoptotic pathways and autophagy did not occur in a subordinated manner. Altogether, our data indicate RBAc as a powerful photosensitiser that induces a prolonged cytotoxicity and time-related cell death onset by signals originating from or converging on almost all intracellular organelles. The fact that cancer cells can die through different mechanisms is a relevant clue in the choice and design of anticancer PDT.

Cell Death and Disease (2011) 2, e169; doi:10.1038/cddis.2011.51; published online 9 June 2011

Subject Category: Cancer

Photodynamic therapy (PDT) is a non-invasive treatment ${ }^{1}$ that involves the administration of a photosensitising drug (PS) and its subsequent activation by light at wavelengths matching the absorption spectrum of the PS. The activation of the PS evokes photochemical reactions that produce lethal toxic agents, such as reactive oxygen species (ROS), which result in cell death and tissue destruction. ${ }^{2}$ In particular, the cytotoxic effect depends on the intracellular localisation of the PS. ${ }^{3}$ Among the various PS useful in PDT protocols, those targeted on mitochondria are very powerful cytotoxic inducers. ${ }^{4}$ However, PS localising in organelles other than mitochondria have been also shown to be efficient in inducing cell death. ${ }^{5-7}$ As the chemical/physical properties of PS define its intracellular localisation, the oxidative stress induced can be directed to a particular sub-cellular organelle modulating the type and the biochemistry of cell death pathway. ${ }^{8}$

In this context, Rose Bengal acetate (RBAc) could have a practical application in PDT, ${ }^{9-10}$ as introduction of acetate groups increases its ability to cross cell membranes and accumulate in cells. RB molecules, restored by cytoplasmic esterases, redistribute through the cytoplasm, inducing multiple organelle photo-damage. ${ }^{11}$ RBAc-mediated PDT is highly efficient to induce cell death in human HeLa cells by apoptosis ${ }^{9-14}$ and autophagy. ${ }^{15}$ It is known that cellular stress can cause the induction of mitotic catastrophe, cellular senescence and/or autophagy, which in many instances accompanies apoptosis. ${ }^{16}$

The fact that cancer cells can die through different mechanisms is a relevant clue in the choice and design of anticancer therapy. In this context, prompt and positive resolution of the cancer is important to know the amount and the type of cell death, that is, apoptosis, necrosis and autophagy, tolerogenic or immunogenic cell death, that are produced by a specific chemotherapy. ${ }^{17}$ Indeed, only few of the chemotherapeutic agents have the capacity to stimulate immunogenic cell death ${ }^{18}$ that combines the cell death induction through stimulation of immune cells, resulting in the immunogenic apoptosis, which differs from normal apoptosis (tolerogenic apoptosis). ${ }^{17}$ Apoptosis, largely induced by PDT, is triggered by different pathways, initiated by

\footnotetext{
${ }^{1}$ Department of Biological and Environmental Science and Technology (Di.S.Te.B.A.), University of Salento, Lecce 73100, Italy

*Corresponding author: L Dini, Department of Biological and Environmental Science and Technology (Di.S.Te.B.A.), University of Salento, Via per Monteroni, Lecce 73100, Italy. Tel: + 39083229 8614; Fax: + 39083229 8937; E-mail: luciana.dini@ unisalento.it

Keywords: Rose Bengal acetate; autophagy; apoptosis; caspases; Bcl-2 family; ROS

Abbreviations: RBAc-PDT, Rose Bengal acetate photodynamic therapy; ROS, reactive oxygen species; Bcl-2, B-cell lymphoma-2; Hsp70, heat-shock protein-70; LC3B, light chain-3B; GRP78, glucose-regulated protein-78; Z-LEHD-FMK, Z-Leu-Glu(OMe)-His-Asp(OMe)-fluoromethylketone; Z-IETD-FMK, Z-Ile-Glu(OMe)-ThrAsp(OMe)-fluoromethylketone; Z-VAD-FMK, benzyloxycarbonyl-Val-Ala-Asp(OMe)-fluoromethylketone; elF2 $\alpha$, eukaryotic initiation factor-2; 3-MA, 3-methyladenine; Nec-1, necrostatin-1; PS, photosensitising drug; ER, endoplasmic reticulum; $\Delta \psi_{\mathrm{m}}$, mitochondrial transmembrane potential; MDC, monodansylcadaverine; TEM, transmission electron microscopy; OMM, outer mitochondrial membrane; MMP, mitochondrial membrane permeabilisation; AlPc, aluminium phtalocyanine; PTPC, permeability transition pore complex; ANT, adenine-nucleotide translocator; VDAC, voltage-dependent anion channel; $\mathrm{Ca}^{2+}$, calcium; AIF, apoptosis-inducing factor; CARD, caspase activation and recruitment domain; Apaf-1, apoptotic protease-activating factor-1; 5-ALA-PDT, 5-aminolaevulinic acid photodynamic therapy; EMEM, Eagle's minimum essential medium; FCS, fetal calf serum; PBS, phosphate-buffered saline; EIA, enzyme immunometric assay; FLICA, fluorescence-labelled inhibitor of caspases; PI, propidium iodide; FITC, fluorescein isothiocyanate; NBT, nitrobluetetrazolium; MTT, 3-(4,5-dimethylthiazol-2-yl)-2,5-diphenyltetrasolium bromide; DMSO, dimethyl sulphoxide
}

Received 23.11.10; revised 12.4.11; accepted 20.4.11; Edited by M Piacentini 
activation of cysteine aspartyl-specific proteases (caspases). ${ }^{19-21}$ Caspase activation is regulated by a variety of factors, among which the $\mathrm{Bcl}-2$ family has a pivotal role. ${ }^{22}$ Autophagy, on the other hand, is a catabolic process involved in energy homeostasis, organelle turnover and in cancer cell death. ${ }^{23}$

To date, the knowledge of the molecular mechanisms involved in the induction of cell death by RBAc-PDT is still scarce. In this work we analysed the temporal activation of the different cell death types induced by RBAc-PDT. To define the onset of apoptotic pathways, we tracked the activation of caspases 3, 8 and 9, and cleavage of caspase-12 during $72 \mathrm{~h}$ of recovery after irradiation; the role of some members of the Bcl-2 family and endoplasmic reticulum (ER) stress. The induction of autophagy was evaluated by detecting the formation of autophagosomes and the presence of the autophagic biomarker light chain-3B-II (LC3BII), and its prodeath or pro-survival role was assessed by using 3-methyladenine (3-MA), an autophagic-specific inhibitor. Finally, we elucidated the independence of both apoptosis and autophagy, and the different apoptotic pathways initiated after RBAc-PDT.

\section{Results}

RBAC-PDT triggered ROS generation. The cytotoxicity of RBAc-PDT is ROS-mediated (Figure 1). Their generation was time-dependent, with a maximum of threefold over that of untreated HeLa cells measured soon after irradiation. ROS levels were always significantly higher than that in untreated cells and decreased progressively with time of recovery (Figure 1a). ROS cytotoxicity was neutralised using the antioxidant vitamin $\mathrm{C}(10 \mu \mathrm{M})$, achieving a partially rescued cell viability and less severe RBAc-PDT toxicity (Figure 1b).

RBAc-PDT induced multiple apoptotic pathways in HeLa cells. The activation of the different pathways of apoptosis generated by RBAc-PDT was determined by quantification of active caspase- 9 (37 and $35 \mathrm{kDa})$, caspase8 (18 kDa) and caspase-3 (17 kDa), and cleaved caspase-12 $(40 \mathrm{kDa})$ during $72 \mathrm{~h}$ of recovery after PDT. Photodynamic treatment triggered the rapid activation of the intrinsic pathway soon after irradiation, as indicated by the presence of active caspase-9 (Figures 2A and B). This, in turn, correlated with the onset of active caspase-3 (Figures $2 \mathrm{~A}$ and $\mathrm{B}$ ), the cytosolic release of cytochrome $c$ (Figure $2 \mathrm{C}$ ) and the early appearance of apoptotic cells, whose number and nuclear fragmentation increased progressively, with a peak at $12 \mathrm{~h}$ after PDT. From $8 \mathrm{~h}$ after PDT, the level of active caspase-9 decreased concomitantly compared with a constant high presence of active caspase-3 during the recovery time, which remained up to $72 \mathrm{~h}$ post PDT, suggesting activation of other apoptotic pathways (Figures $2 A$ and $B$ ). In fact, the level of active caspase- 8 was found to be five-fold over that in untreated cells at $8-12 \mathrm{~h}$ of recovery and $\mathrm{Hsp} 70$ protein peaked at $12-18 \mathrm{~h}$ after PDT (Figure 2A).

RBAc-PDT also induced caspase-12-dependent apoptosis (Figure 3). In fact, the cleaved form of caspase-12 was markedly detected from $18 \mathrm{~h}$ up to the end of recovery
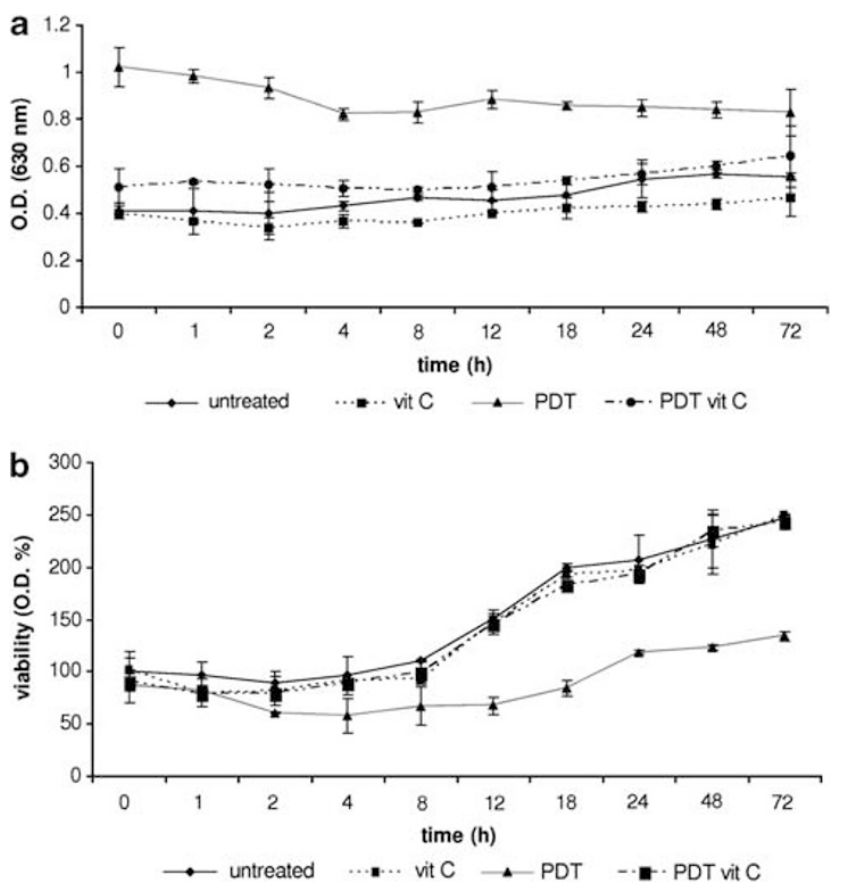

Figure 1 ROS levels and viability of RBAC-PDT-treated HeLa cells. (a) ROS levels were detected by using NBT assay as reported under Materials and Methods. The values are reported as optical density (OD) measured at $630 \mathrm{~nm}$. ROS production was measured in photosensitised HeLa cells and in untreated cells, or cells incubated with vitamin $C$ alone or in combination with photodynamic treatment. Each value represents the mean \pm S.D. of three independent experiments. All PDT values are significantly different $(P<0.05)$ with respect to untreated and vitamin C-PDT cells. (b) Viability was assessed by MTT assay. The values are reported as percentage of OD measured at $570 \mathrm{~nm}$ of the untreated HeLa cells considered as $100 \%$. Each value represents the mean \pm S.D. of three independent experiments. All PDT values are significantly different $(P<0.05)$ with respect to vitamin C-PDT cells

(Figures 3B and D). In order to confirm the real involvement of this pathway, two ER stress markers, glucose-regulated protein (GRP78) and eukaryotic initiation factor-2 $\alpha$ (elF2 $\alpha$ ) were analysed. Overexpression of GRP78, two-fold over that in untreated cells from $18 \mathrm{~h}$ up to the end of recovery, and we observed an increment of the P-elF2 $\alpha /$ elF $2 \alpha$ ratio, approximately two-fold at $24 \mathrm{~h}$ of recovery (Figures $3 \mathrm{~A}, \mathrm{~B}$ and $\mathrm{D}$ ).

The pan-caspase inhibitor, Z-VAD, failed to completely prevent apoptosis, supporting the involvement of a caspaseindependent apoptotic pathway. Indeed, in the presence of Z-VAD and 3-MA, $10 \%$ of Annexin-V-positive HeLa cells were found from $12 \mathrm{~h}$ up to the end of recovery (Table 1 ).

Bcl-2 family members regulated the intrinsic apoptotic pathway. The level of Bcl-2 increased dramatically (four-fold over that in untreated cells) in the cytoplasm from $8 \mathrm{~h}$ after PDT, whereas it decreased in the membrane protein pool within $4 \mathrm{~h}$ of recovery. The highest cytosolic amount of Bcl-2 was measured at 48 and $72 \mathrm{~h}$ of recovery (respectively, 8- and 10-fold that in untreated cells) (Figures 2D-F).

RBAc-PDT induced an early reduction of mitochondrial transmembrane potential $\left(\Delta \psi_{\mathrm{m}}\right)$ in HeLa cells, ${ }^{12,13}$ and an extensive cytochrome $c$ release into the cytosol as early as $1 \mathrm{~h}$ after PDT (Figure 2C). The simultaneous increase of Bax-Bax 
A

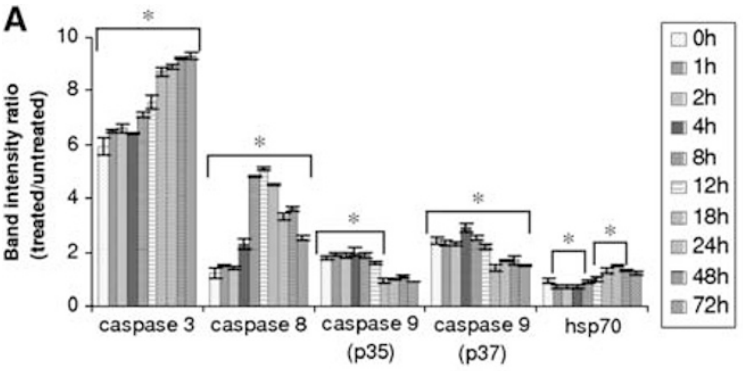

C

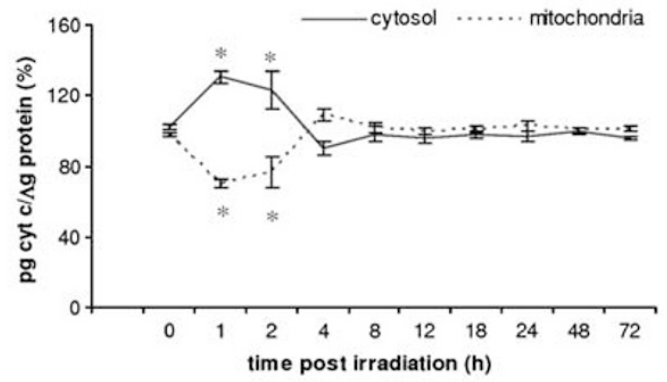

E

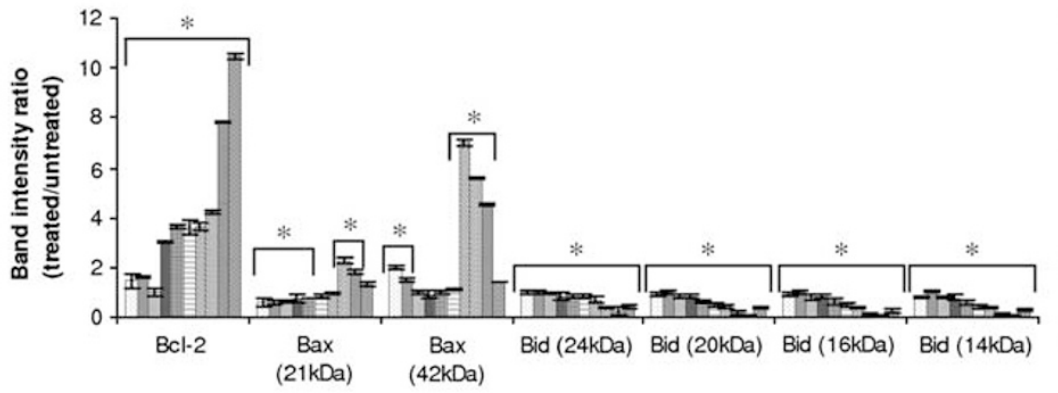

$\mathbf{F}$

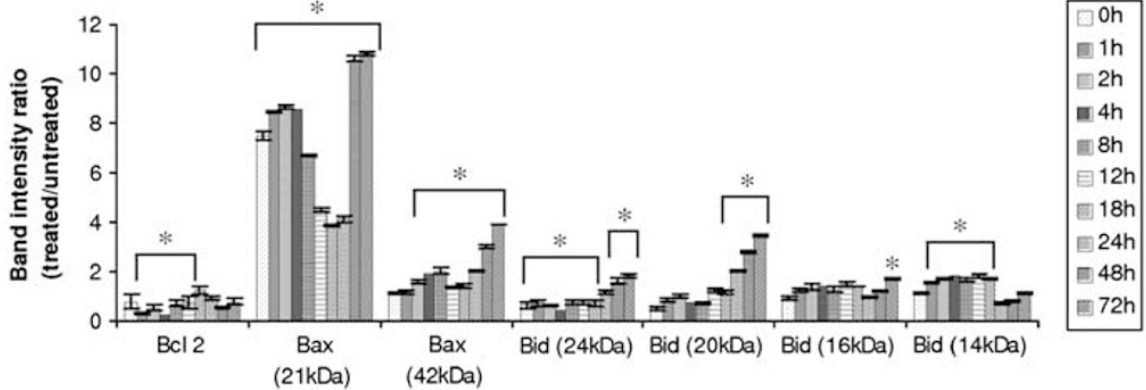

Figure 2 Induction of apoptosis. Time-dependent cleavage of caspases (A and B), cytochrome $c$ release (C), and expression of Bcl-2 family member proteins (D-F) and cytosolic Hsp70 (A). The cytosolic (A-E) and membrane (F) fractions (30 $\mu \mathrm{g}$ protein/lane) of RBAc-PDT $\left(10^{-5} \mathrm{M} \mathrm{RBAc}, 1 \mathrm{~h}, 1.6 \mathrm{~J} / \mathrm{cm}^{2}, 90 \mathrm{~s}\right)$-treated HeLa cells at the indicated time points after PDT were collected and assayed by western blotting, and developed using monoclonal antibodies against caspase-3, caspase-8, caspase-9, $\mathrm{Hsp} 70, \mathrm{Bcl}-2$, Bax and Bid proteins. Antibodies detected cleaved products of caspases-3 (17 kDa), caspase-8 (18 kDa), caspase-9 (37 and $35 \mathrm{kDa})$, and $\mathrm{Hsp} 70$, Bcl-2 (26 kDa), Bax (21 and $42 \mathrm{kDa}$ ) and Bid $(24,20,16,14 \mathrm{kDa})$. $\beta$-Actin was used as loading control. All blots shown (B-D) are representative of three experiments. The densitometric analysis is reported as band intensity of the proteins under investigation normalised to that of untreated HeLa cells. The results are the mean \pm S.D. of three independent experiments. *significantly different $(P<0.05)$ with respect to untreated cells. The lower images in panel $\mathbf{B}$ show fluorescence micrographs of active caspase-3 in RBAc-PDT-treated HeLa cells at $24 \mathrm{~h}$ of recovery after PDT. The cells were co-stained with Hoechst + FLICA to visualise nuclei fragmentation (a; excitation, $365 \mathrm{~nm}$; emission, $480 \mathrm{~nm}$ ) and caspase activation (b; excitation, $490 \mathrm{~nm}$; emission, $516 \mathrm{~nm}$ ), as reported under Materials and Methods. Phase-contrast micrographs of RBAc-PDTtreated HeLa cells at $24 \mathrm{~h}$ of recovery after PDT (c). Bars $=10 \mu \mathrm{m}$. (C) RBAc-PDT $\left(10^{-5} \mathrm{M}\right.$ RBAc, $\left.1 \mathrm{~h}, 1.6 \mathrm{~J} / \mathrm{cm}^{2}, 90 \mathrm{~s}\right)$-treated HeLa cells were harvested at various time points after PDT for the content of cytosolic and mitochondrial cytochrome $c$, whose concentrations, detected by ELISA assay, are expressed as percentage of pg cyt $c / \mu \mathrm{g}$ of protein with respect to untreated values considered as $100 \%$. ${ }^{*}$ significantly different $(P<0.05)$ with respect to the control

homodimers $(42 \mathrm{kDa})$ in the fraction of membrane proteins was always significantly higher than that in non-photosensitised cells up to the end of recovery (Figures $2 \mathrm{D}$ and $\mathrm{F}$ ).
Conversely, the levels of cytosolic Bax-Bax homodimers were approximately 7 - and five-fold the value in untreated cells from 18 to $48 \mathrm{~h}$ after PDT, respectively (Figures 2D 

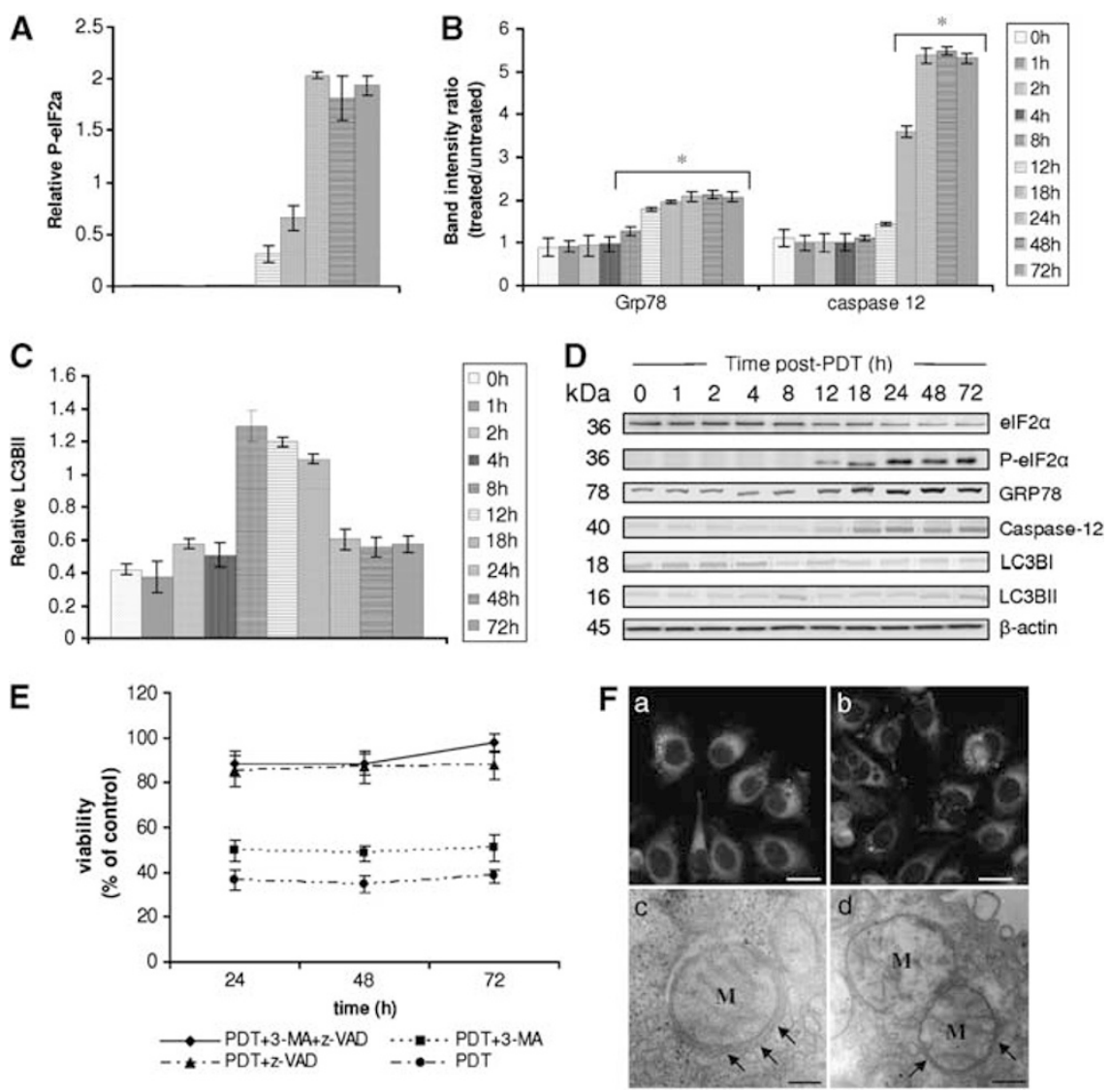

Figure 3 ER stress and induction of autophagy. Time-dependent phosphorylation of elF2 $\alpha(A)$, overexpression of GRP78 (B), cleavage of caspase-12 (B) and expression of LC3BII protein (C). The cytosolic (A-C) and membrane (C) fractions (30 $\mu \mathrm{g}$ protein/lane) of RBAc-PDT $\left(10^{-5} \mathrm{M} \mathrm{RBAc}, 1 \mathrm{~h}, 1.6 \mathrm{~J} / \mathrm{cm}^{2}, 90 \mathrm{~s}\right)$-treated HeLa cells at the indicated time points after PDT were collected and assayed by western blotting, and developed using monoclonal antibodies against elF2 $\alpha$, P-elF2 $\alpha$, GRP78, caspase-12 and LC3BI-II proteins. Antibodies detected cleaved products of caspase-12 (p40), GRP78 (78 kDa), elF2 $\alpha$ (36 kDa), LC3BI (18 kDa) and LC3BII (16 kDa). $\beta$-Actin was used as loading control. The densitometric analysis is reported as band intensity of P-elF2 $\alpha$ protein normalised to elF2 $\alpha$ (a); GRP78 and caspase-12 normalised to untreated HeLa cells (B); and the LC3BII protein normalised to LC3BI (C). The results are the mean \pm S.D. of three independent experiments. All blots shown (D) are representative of three experiments. *, significantly different $(P<0.05)$ with respect to untreated cells. $(E)$ Viability of RBAc-PDT-treated HeLa cells in the presence of 3-MA and Z-VAD was assessed by MTT assay. The values are reported as percentage of optical density (OD) measured at $570 \mathrm{~nm}$, normalised to untreated HeLa cells considered as $100 \%$. Each value represents the mean \pm S.D. of three independent experiments. All PDT $+3-\mathrm{MA}$ values are significantly different $(P<0.05)$ with respect to PDT cells. $(\mathbf{F})$ Fluorescence microscopic micrographs of MDC ( $0.05 \mathrm{mM}$ )-labelled, RBAc-PDT HeLa cells at 4 (a) and $8 \mathrm{~h}$ (b) of recovery. Bars $=10 \mu \mathrm{m}$. Electron microscopic (TEM) micrographs of HeLa cells at 4 (c) and $8 \mathrm{~h}$ (d) of recovery after PDT treatment, showing the presence of autophagosomes. The arrows indicate a double-membrane structure. M indicates mitochondria. Bars $=0.5 \mu \mathrm{m}$

and E). The membrane-associated Bax monomers (21 kDa) increased soon after irradiation and at the longest time periods $(48-72 \mathrm{~h}$ ) of recovery, whereas their level progressively decreased in the cytoplasm. The levels of Bax monomers were approximately 2.3-fold the value in the cytoplasm of untreated cells at $24 \mathrm{~h}$ of recovery.

There was significant decrease in the level of Bid $(24 \mathrm{kDa})$ in the cytosol, which was approximately 1.5 - and 2.5 -fold the values in untreated cells between 18 and $72 \mathrm{~h}$ of recovery, respectively (Figures $2 \mathrm{D}$ and $\mathrm{E}$ ). The $20-, 16-$ and $14-\mathrm{kDa}$ truncated forms of Bid (tBids) were detected within $1 \mathrm{~h}$ of recovery in the cytosol (Figures 2D and E), from where they disappeared (from 18 to $48 \mathrm{~h}$ after PDT) concomitantly to their increment in the membrane protein pool (Figures 2D and F).

RBAC-PDT induced autophagy in HeLa cells. Morphological and biochemical assays, that is, monodansylcadaverine (MDC) staining, transmission electron microscopy (TEM) and LC3BII expression, allowed us to identify autophagy in photosensitised HeLa cells (Figures 3D, C and F, respectively). The peak of autophagy (25\%) was measured at $8 \mathrm{~h}$ of recovery (Table 1). Characteristic autophagosomes with a double membrane surrounding damaged mitochondria are shown in the transmission electron micrographs in Figures $3 \mathrm{~F}, \mathrm{c}$ and d. Acidic vesicles of autophagic cells were stained with MDC (Figures $3 \mathrm{~F}, \mathrm{a}$ and $\mathrm{b}$ ). Induction of autophagy was further supported by the conversion of LC3BI to LC3BII at $8 \mathrm{~h}$ after PDT (Figures $3 \mathrm{C}$ and $\mathrm{D}$ ).

Suppression of autophagy with 3-MA during RBAc photosensitisation rescued $40 \%$ of cell viability with respect to RBAc-PDT HeLa cells, suggesting a pro-death role of autophagy (Figure 3E).

The different cell death types occurred independently during RBAc-PDT. Tables $1-3$ show the effect of selective 


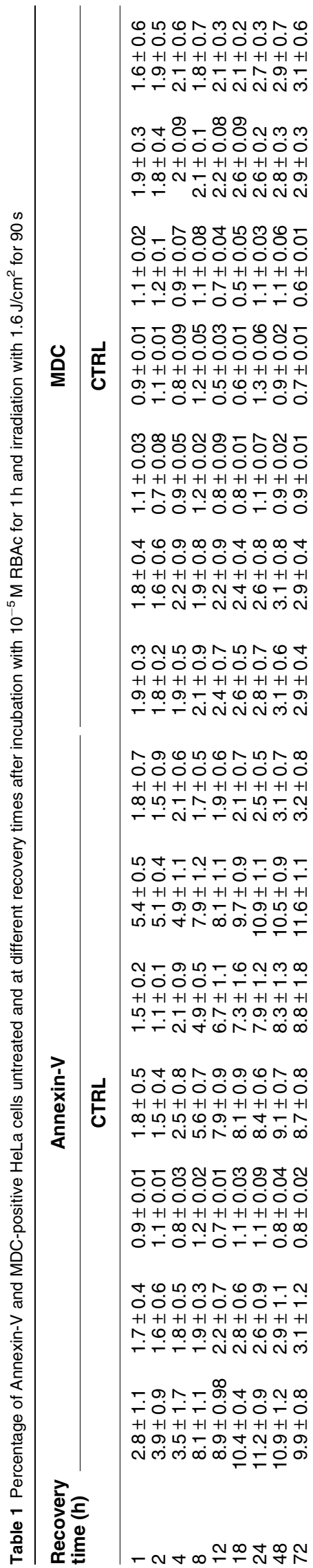

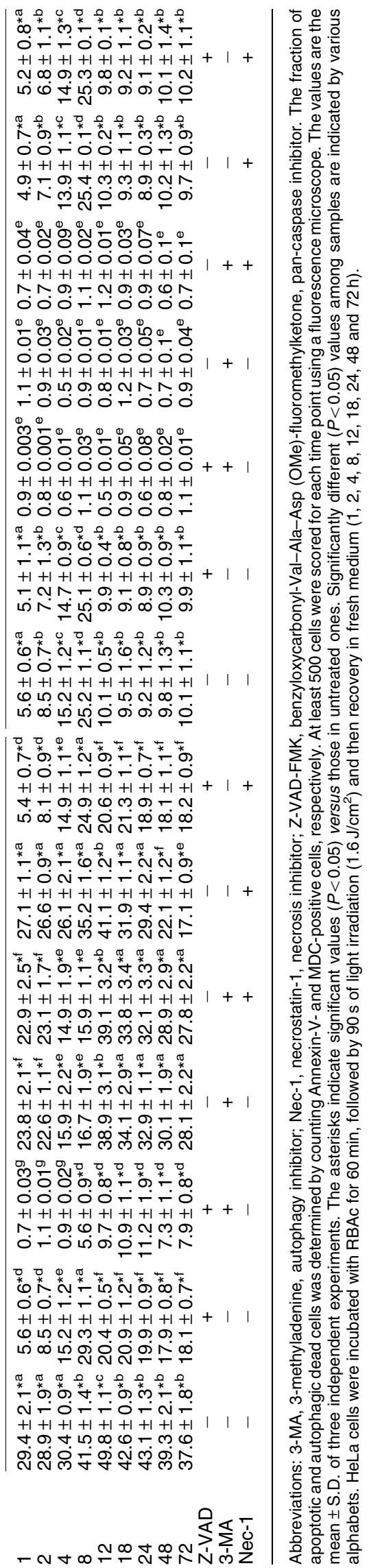


Table 2 Percentage of Annexin-V-positive HeLa cells untreated and at different recovery time points after incubation with $10^{-5} \mathrm{M}$ RBAc for $1 \mathrm{~h}$ and irradiation with $1.6 \mathrm{~J} / \mathrm{cm}^{2}$ for $90 \mathrm{~s}$

\begin{tabular}{|c|c|c|c|c|c|}
\hline Recovery time (h) & \multicolumn{5}{|c|}{ CTRL } \\
\hline 1 & $2.8 \pm 1.1$ & $2.9 \pm 0.6$ & $2.7 \pm 0.9$ & $1.7 \pm 0.4$ & $2.8 \pm 0.9$ \\
\hline 2 & $3.9 \pm 0.9$ & $2.6 \pm 0.5$ & $2.8 \pm 1.1$ & $1.6 \pm 0.6$ & $2.4 \pm 0.9$ \\
\hline 4 & $3.5 \pm 1.7$ & $3.1 \pm 0.3$ & $3.2 \pm 0.8$ & $1.8 \pm 0.5$ & $2.1 \pm 0.7$ \\
\hline 8 & $8.1 \pm 1.1$ & $5.6 \pm 0.5$ & $5.2 \pm 1.1$ & $1.9 \pm 0.3$ & $3.1 \pm 1.1$ \\
\hline 12 & $8.9 \pm 0.98$ & $4.9 \pm 0.6$ & $4.8 \pm 0.5$ & $2.2 \pm 0.7$ & $2.9 \pm 1.2$ \\
\hline 18 & $10.4 \pm 0.4$ & $6.1 \pm 0.6$ & $5.9 \pm 1.1$ & $2.8 \pm 0.6$ & $3.2 \pm 0.9$ \\
\hline 24 & $11.2 \pm 0.9$ & $6.5 \pm 1.1$ & $6.4 \pm 1.2$ & $2.6 \pm 0.9$ & $3.4 \pm 0.8$ \\
\hline 48 & $10.9 \pm 1.2$ & $7.1 \pm 1.2$ & $6.9 \pm 1.1$ & $2.9 \pm 1.1$ & $2.9 \pm 0.6$ \\
\hline 72 & $9.9 \pm 0.8$ & $7.4 \pm 1.3$ & $7.2 \pm 0.9$ & $3.1 \pm 1.2$ & $2.8 \pm 0.6$ \\
\hline & & & RBAc-PDT & & \\
\hline 1 & $29.4 \pm 2.1^{\star a}$ & $30.5 \pm 1.7^{\star a}$ & $4.5 \pm 1.1^{\star \mathrm{e}}$ & $5.6 \pm 0.6^{\star \mathrm{e}}$ & $2.8 \pm 1.3^{g}$ \\
\hline 2 & $28.9 \pm 1.9^{\star a}$ & $29.9 \pm 0.9^{\star a}$ & $5.2 \pm 0.8^{\star \mathrm{e}}$ & $8.5 \pm 0.7^{\star \mathrm{e}}$ & $2.5 \pm 0.9^{g}$ \\
\hline 4 & $30.4 \pm 0.9^{\star a}$ & $31.5 \pm 0.2^{\star a}$ & $4.9 \pm 0.7^{\star \mathrm{e}}$ & $15.2 \pm 1.2^{\star f}$ & $14.9 \pm 0.7^{\star f}$ \\
\hline 8 & $41.5 \pm 1.4^{\star \mathrm{b}}$ & $39.9 \pm 1.1^{\star b}$ & $31.5 \pm 1.6^{\star a}$ & $25.2 \pm 1.1^{\star a}$ & $26.4 \pm 1.1$ *a \\
\hline 12 & $49.8 \pm 1.1^{\star \mathrm{c}}$ & $23.5 \pm 2.3^{\star d}$ & $32.6 \pm 2.1^{\star a}$ & $20.4 \pm 0.5^{\star a}$ & $26.9 \pm 1.4^{\star a}$ \\
\hline 18 & $42.6 \pm 0.9^{\star b}$ & $24.9 \pm 1.9^{\star d}$ & $30.1 \pm 1.1^{\star a}$ & $20.9 \pm 1.2^{\star a}$ & $27.1 \pm 1.6^{\star a}$ \\
\hline 24 & $43.1 \pm 1.3^{\star b}$ & $23.6 \pm 1.4^{\star d}$ & $31.4 \pm 0.9^{\star \mathrm{a}}$ & $19.9 \pm 0.9^{\star a}$ & $26.3 \pm 1.3^{\star a}$ \\
\hline 48 & $39.3 \pm 2.1^{\star b}$ & $21.5 \pm 1.8^{\star d}$ & $29.8 \pm 1.1^{\star a}$ & $17.9 \pm 0.8^{\star a}$ & $25.9 \pm 1.1$ *a \\
\hline 72 & $37.6 \pm 1.8^{\star b}$ & $22.1 \pm 2.3^{\star d}$ & $31.2 \pm 1.7^{\star a}$ & $18.1 \pm 0.7^{\star \mathrm{a}}$ & $25.4 \pm 0.9^{\star a}$ \\
\hline Z-IETD-FMK & - & + & - & - & + \\
\hline Z-LEHD-FMK & - & - & + & - & + \\
\hline Z-VAD-FMK & - & - & - & + & $-s$ \\
\hline
\end{tabular}

Abbreviations: Z-IETD-FMK, Z-Ile-Glu(OMe)-Thr-Asp(OMe)-fluoromethylketone, caspase-8 inhibitor; Z-LEHD-FMK, Z-Leu-Glu(OMe)-His-Asp(OMe)-fluoromethylketone, caspase-9 inhibitor; Z-VAD-FMK, benzyloxycarbonyl-Val-Ala-Asp(OMe)-fluoromethylketone, pan-caspase inhibitor. The fraction of apoptotic dead cells was determined by counting Annexin-V-positive HeLa cells. At least 500 cells were scored for each time point using a fluorescence microscope. The values are the mean \pm S.D. of three independent experiments. The asterisks indicate significant values $(P<0.05)$ versus those in untreated ones. Significantly different $(P<0.05)$ values among samples are indicated by various alphabets. HeLa cells were incubated with RBAc for $60 \mathrm{~min}$, followed by $90 \mathrm{~s}$ of light irradiation $\left(1.6 \mathrm{~J} / \mathrm{cm}^{2}\right)$ and then recovery in fresh medium $(1,2,4,8,12,18,24,48$ and $72 \mathrm{~h})$.

caspase-9 (Z-LEHD-FMK (Z-Leu-Glu(OMe)-His-Asp(OMe)fluoromethylketone)), caspase-8 (Z-IETD-FMK (Z-Ile$\mathrm{Glu}(\mathrm{OMe})-\mathrm{Thr}-\mathrm{Asp}(\mathrm{OMe})$-fluoromethylketone)), pancaspase (Z-VAD-FMK (benzyloxycarbonyl-Val-Ala-Asp (OMe)-fluoromethylketone)), autophagy (3-MA) and necrosis (necrostatin-1 (Nec-1)) inhibitors on the rate of cell death over the course of $72 \mathrm{~h}$ of recovery after PDT.

Inhibition of autophagy with 3-MA, apoptosis with Z-VAD and necrosis with $\mathrm{Nec}-1$, alone or in combination, did not interfere with the onset and rate of apoptosis, autophagy and necrosis (Table 1). Similarly, the contribution to the rate of cell deaths generated by the extrinsic apoptotic pathway in the presence of the specific inhibitor of the intrinsic pathway, was unchanged with respect to RBAc-PDT and vice versa (Table 2).

\section{Discussion}

To our knowledge, this is the first report showing that the photosensitiser RBAc is able to efficiently and independently induce multiple cell death types, that is, apoptosis and autophagy. Through this work RBAc has been further confirmed as a very promising photosensitising drug as it ensures long-term cytotoxic effects by induction of relevant percentage of apoptosis and autophagy in a time-related manner after PDT. Photo-killing has been shown to involve the intrinsic or mitochondrial apoptotic pathway in virtually all PDTs studied so far. ${ }^{7}$ Here we provide evidence that HeLa cells exploit multiple pathways to induce apoptosis after RBAc-PDT. Indeed, apoptosis is the first preferred mechanism of death in our system and it is triggered by at least four different pathways (Figure 4), whose independent temporal activation ensures cell killing when one or several of the apoptotic pathways are inactivated. Apoptosis occurred as early as $1 \mathrm{~h}$ after irradiation by activation of the intrinsic pathway, followed by the activation of the extrinsic, caspase12-dependent and caspase-independent pathways. Apoptosis was then followed rapidly by autophagy.

The crucial event responsible for cell death induction was the prompt ROS generation after irradiation, whose amount and site of generation is thought to determine the damage of cellular components and the triggering of several signalling pathways, including cell death. ${ }^{24}$ Indeed, as ROS accumulation occurred upstream to all RBAc-PDT-induced apoptotic events, is likely that the quick generation of ROS provoked mitochondrial damage that, in turn, activated the intrinsic apoptotic pathway. Immediately after irradiation, the Bcl-2 family members regulated the loss of $\Delta \psi_{\mathrm{m}}{ }^{13}$ and the consequent cytosolic release of cytochrome $c$, ending in the cleavage cascade of caspase- 9 and caspase-3. In fact, loss of $\Delta \psi_{\mathrm{m}}$, owing to opening of the transition pore complex that permeabilises the outer mitochondrial membrane (OMM), is a very early event (1-2 $\mathrm{h}$ after PDT), ${ }^{13}$ even if mitochondria are not the primary target of RBAc. Mitochondrial membrane permeabilisation (MMP) after PDT is a crucial lethal event, which is tightly controlled by Bcl-2 family members. Our data are in line with those indicating pro-apoptotic Bcl-2 family members as a critical gateway to the permeabilisation of the OMM in photosensitised cells, and confirm the regulatory role of these proteins of the intrinsic pathway, through mitochondrial regulation. ${ }^{22}$ However, the pro- or antiapoptotic role of $\mathrm{Bcl}-2$ proteins in PDT-mediated apoptosis is not yet 
Table 3 Time-related onset of the different cell death types generated by RBAc-PDT in HeLa cells

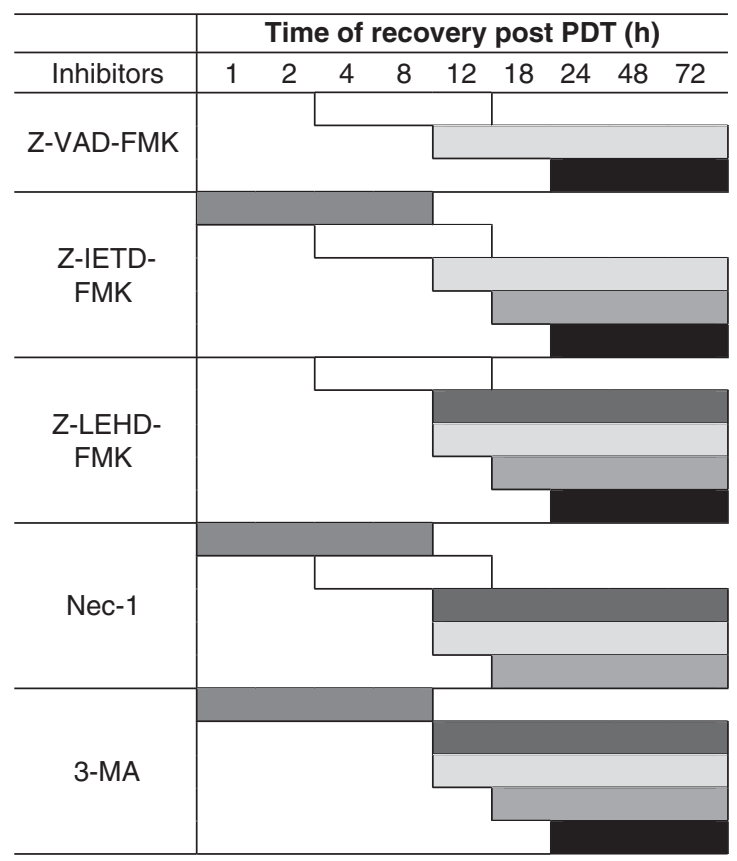

Autophagy

Caspase-independent apoptotic pathway

Caspase-12-dependent apoptotic pathway

Intrinsic apoptotic pathway

Extrinsic apoptotic pathway

Secondary necrosis

Abbreviations: 3-MA, 3-methyladenine, autophagy inhibitor; Nec-1, necrostatin-1, necrosis inhibitor; Z-IETD-FMK, Z-Ile-Glu(OMe)-Thr-Asp(OMe)-fluoromethylketone, caspase-8 inhibitor; Z-LEHD-FMK, Z-Leu-Glu(OMe)-HisAsp(OMe)-fluoromethylketone, caspase- 9 inhibitor; Z-VAD-FMK, benzyloxycarbonyl-Val-Ala-Asp(OMe)-fluoromethylketone, pan-caspase inhibitor. HeLa cells were incubated with $10^{-5} \mathrm{M} \mathrm{RBAc}$ for $1 \mathrm{~h}$ and irradiated with $1.6 \mathrm{~J} / \mathrm{cm}^{2}$ for $90 \mathrm{~s}$ in the presence of different inhibitors of cell death. Cells were analyzed during $72 \mathrm{~h}$ of recovery after irradiation.

established convincingly. For instance, in HeLa cells overexpressing Bcl-2, partial protection from verterporfinmediated apoptosis has been observed; ${ }^{25}$ paradoxically, in MCF10A cells photosensitised with aluminium phthalocyanine (AIPc), increased levels of Bcl-2 enhanced the efficiency of photo-killing. ${ }^{26}$ Probably, photo-generation of ROS represents a signal in the delocalisation and insertion of Bax on the $\mathrm{OMM}^{27}$ In fact, the molecular mechanisms of activation of Bax are not completely understood and they are only speculative in PDT. Our data on the levels of Bax monomers and Bax-Bax dimers in the cytosol and in membrane proteins pool are in agreement with the findings that relocation of Bax from the cytosol to the mitochondria occurs before release of cytochrome $c{ }^{28}$ An exception is provided by smooth-muscle cells photosensitised with verteporfin, where translocation of Bax to mitochondria was detected secondary to the release of cytochrome $c{ }^{29}$ We hypothesised that membrane-associated Bax monomers could engage a close molecular cooperation with proteins from the permeability transition pore complex (PTPC), such as adenine-nucleotide translocators (ANTs) or voltage-dependent anion channels (VDACs), to induce MMP. Alternatively, Bax, inserted as monomer in the OMM, destabilised the lipid bilayer, allowing the release of cytochrome $c .^{20}$ Indeed, the drastic reduction of $\Delta \psi_{\mathrm{m}}{ }^{13}$ may depend on molecular openings induced by Bax-Bax dimers as suggested by their increment on membrane proteins pool.

A signal for the loss of $\Delta \psi_{\mathrm{m}}$ could be the dramatic and specific photo-induced oxidation of $\mathrm{Bcl}-2$, with loss of its function. ${ }^{30}$ These events interfere with the antiapoptotic function of $\mathrm{Bcl}-2$ on the OMM and act as a permissive signal to induce Bax-mediated MMP. Thus, the observed decrement of $\mathrm{Bcl}-2$ in the cytosol could probably be because of loss of function of the protein, induced by photosensitisation with RBAc. It is known that $\mathrm{Bcl}-2$ protein associated to $\mathrm{ER}$ can be photo-damaged by PDT. ${ }^{30}$ Other signals able to activate Bax could not be excluded, such as alteration of calcium $\left(\mathrm{Ca}^{2+}\right)$ homeostasis caused by photodynamic reactions developed in the $\mathrm{ER}$, which is the main store of $\mathrm{Ca}^{2+}$ in the cell. We have already reported that $\left[\mathrm{Ca}^{2+}\right]_{i}$ increases in photosensitised cells soon after $1 \mathrm{~h}$ after RBAc-PDT, the time in which loss of function of Bcl-2 and activation of Bax were observed. Moreover, increment of $\left[\mathrm{Ca}^{2+}\right]_{\mathrm{i}}, 12 \mathrm{~h}$ after PDT, corresponds to the peak of apoptosis and to the dramatic damage of the ER. ${ }^{13,15}$

$\mathrm{Bcl}-2$ family proteins also regulated the intrinsic pathway through activation of Bid, which is a molecular cross-talk between the extrinsic and the intrinsic pathway. Bid is cleaved by caspase- 8 in a truncated form (tBid), which translocates from the cytosol to the OMM, mediating pore formation. ${ }^{22}$ Indeed, from 12 to $18 \mathrm{~h}$ after PDT, whereas native Bid decreased in the cytosol, tBid increased in the membrane proteins pool. As RBAc-PDT influences lysosomes, ${ }^{12,13}$ the Bid protein can be fragmented not only by active caspase- 8 but also by cathepsin released in the cytosol after alteration of the lysosomal membrane. ${ }^{31}$

The high level of cleaved caspase-3 during the entire recovery time, even when the level of active caspase- 9 was negligible, indicated activation of other caspases, such as caspase- 8 and, to a lesser extent, caspase-12. Indeed, our data show that, in RBAc-PDT, apoptosis was further induced by activation of the extrinsic pathway (from 12 to $72 \mathrm{~h}$ of recovery), the caspase-12-dependent pathway (from $18 \mathrm{~h}$ to $72 \mathrm{~h}$ of recovery) and the caspase-independent pathway (from 12 to 72 of recovery) (Table 3). Caspase-12-dependent apoptosis was triggered by ER stress, as suggested by phosphorylation of elF $2 \alpha$ and upregulation of GRP78. The pan-caspase inhibitor Z-VAD confirmed the involvement of the caspase-independent pathway. Accordingly, Bottone et $a l^{32}$ reported that the apoptosis-inducing factor (AIF) translocates from mitochondria to the nucleus from 24 to $72 \mathrm{~h}$ after RBAc PDT, indicating the involvement of a caspaseindependent pathway.

A substantial contribution to the killing of tumour cells was also provided by induction of autophagy and ER stress. These 

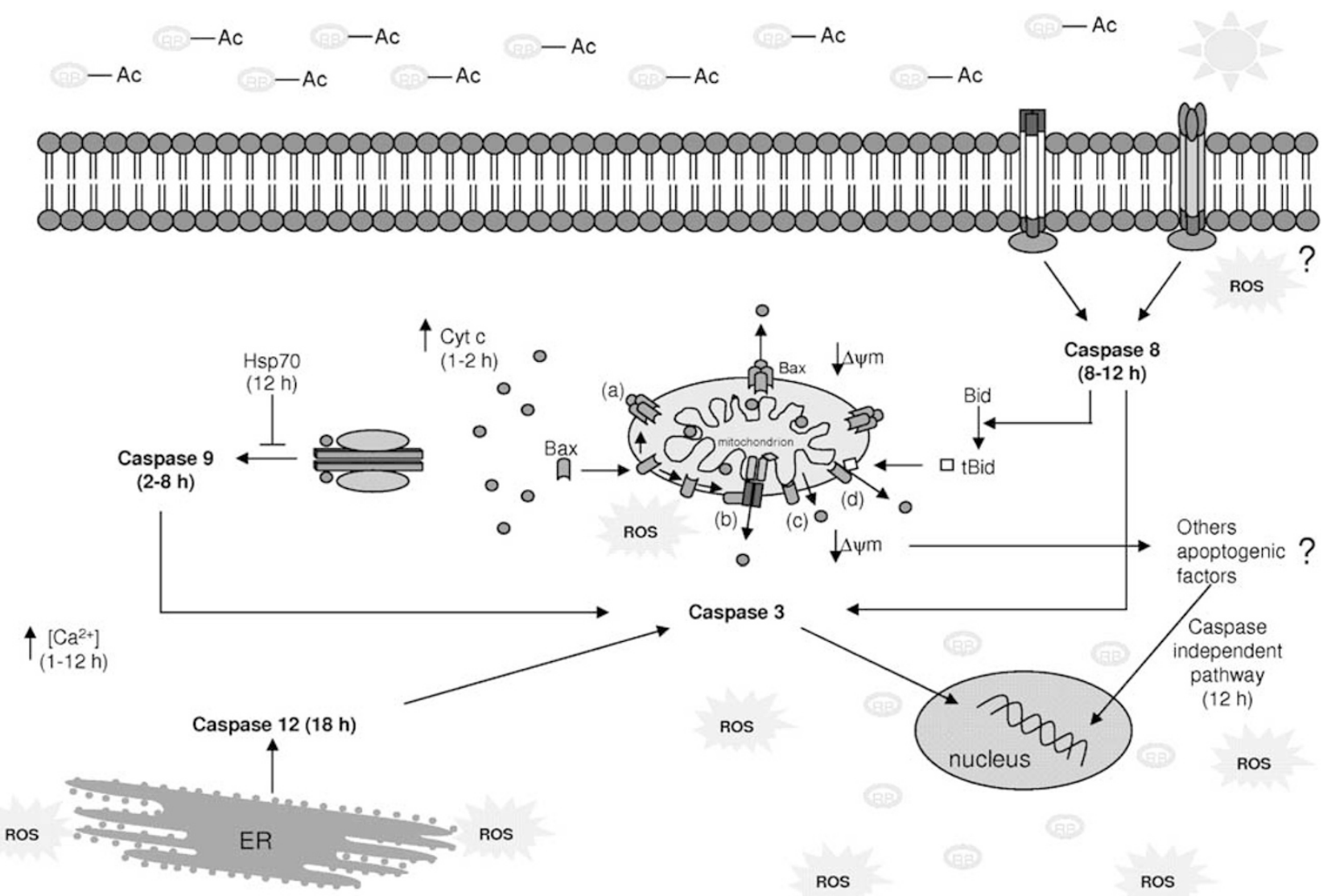

\section{.}


the intensity or duration of ER damage cannot be restored by this response, ER stress can also lead to cell death. ${ }^{37}$ Likewise, autophagy can help to cope with ER stress or participate in the mechanism of ER stress-induced cell death. Thus, ER stress and autophagy can activate both pro-survival mechanisms as well as lethal programs, depending on the type of cancer and cytotoxic agents used. In our experimental system, both ER stress and autophagy promoted cell death. In terms of therapeutic outcome, drugs/treatments capable of activating the proapoptotic branch of ER stress and autophagy, while simultaneously inhibiting their pro-survival function, should provide the highest therapeutic benefit.

Interestingly, temporal activation of apoptosis and autophagy in RBAc-PDT ensures cell death when one or several of these pathways are inactivated. Indeed, in our system all these pathways are exploited independently, thus inhibition of one or more than one pathway is ineffective in blocking or delaying the onset of cell deaths, and in regulating the percentage of dead cell generated by the non-inhibited pathways. Conversely to the data of Granville et al. ${ }^{28}$ showing that, when the intrinsic pathway is suppressed or not activated perfectly, the apoptosis commitment is mediated by the extrinsic pathway, in our system, the activation of the extrinsic apoptotic pathway is independent of the suppression of the intrinsic one or any other. Possible reasons could be ROS, which, besides its crucial role in mitochondrial damage, could also be an important factor in the processing of cell death receptor activation and subsequently activation of caspase-8. ROS could also have a significant role in the trimerisation of membrane receptors, favoured by binding of RBAc to the plasma membrane and the very short distance of diffusion of singlet oxygen. ${ }^{38}$ In addition, the role of $\mathrm{Hsp} 70$ proteins in the activation of the extrinsic pathway at $12 / 18 \mathrm{~h}$ after irradiation must be also taken into account. Indeed, the Hsp70 protein is a negative regulator of mitochondrial pathway of apoptosis, as it binds to the caspase activation and recruitment domain (CARD) of apoptotic protease-activating factor-1 (Apaf-1), preventing apoptosome complex formation. ${ }^{39} \mathrm{We}$ found that the level of free Hsp70 in the cytosol largely increased from 18 to $72 \mathrm{~h}$ after RBAc-PDT, displacing pro-caspase- 9 from the apoptosome. Accordingly, inhibition of caspase-8 did not prevent the activation of the intrinsic and caspase-12dependent pathways.

We found that necrosis was always negligible and HeLa cell death was preferentially executed through apoptosis and autophagy. Thus, as autophagy is a quality-control mechanism involved in the removal of ROS-damaged proteins and organelles, ${ }^{23}$ it is plausible that reducing ROS damage by autophagic degradation limits necrotic cell death in our paradigm. In fact, Coupienne et al. ${ }^{40}$ suggest that 5-aminolaevulinic acid-PDT (5-ALA-PDT) in human glioblastoma LN18 and U87 cell lines induces autophagy, with a protective role against necrosis.

In summary, based on the results discussed above, it can be stated that the main advantage of using RBAc-PDT is that, several signalling processes are initiated in exposed cells, leading to rapid, independent and successive onset of different cell death types. This allows also a significant percentage of tumour dead cells when one or more death pathways are inhibited or lacking. Consequently, RBAc is a powerful cytotoxic PDT photosensitiser that is able to induce a long-lasting and time-related cell death onset by signals originating from or converging on almost all intracellular organelles. Indeed, RBAc-PDT cell damage involves several organelles, that is, mitochondria, lysosomes, Golgi apparatus and ER, despite RBAc primary perinuclear intracellular localisation. ${ }^{11}$

\section{Materials and Methods}

Chemicals. A stock solution $\left(10^{-2} \mathrm{M}\right)$ was obtained by diluting RBAc in dimethyl sulphoxide: the solution, at a final concentration of $10^{-5} \mathrm{M}$, was added directly to the culture medium. All other chemicals used were of the highest purity commercially available. Unless otherwise stated, all chemicals are purchased from Sigma-Aldrich Chem. Co. (St. Louis, MO, USA).

Cell culture. The human cervical carcinoma HeLa cell line was cultured in Eagle's minimum essential medium (EMEM) (Cambrex, Verviers, Belgium) supplemented with $10 \%$ fetal calf serum (FCS), $2 \mathrm{mM}$ L-glutamine (Cambrex), $100 \mathrm{IU} / \mathrm{ml}$ penicillin and streptomycin solution, and $10000 \mathrm{U} / \mathrm{ml}$ nystatin (antimycotic solution) (Cambrex), in a $5 \% \mathrm{CO}_{2}$ humidified atmosphere at $37^{\circ} \mathrm{C}$. The cells were maintained in $75 \mathrm{~cm}^{2}$ flasks (at a cell concentration of $2 \times 10^{5} / 1 \times 10^{6} \mathrm{cells} / \mathrm{ml}$ ) by passage every $3-4$ days.

PDT treatment. Cells were incubated with RBAc $\left(10^{-5} \mathrm{M}\right)$ in EMEM medium supplemented with $10 \% \mathrm{FCS}$ for $60 \mathrm{~min}$ at $37^{\circ} \mathrm{C}$. After incubation, the culture medium was replaced with phosphate-buffered saline (PBS) $(0.2 \mathrm{M}, \mathrm{pH} 7.4)$, previously allowed to equilibrate with $5 \% \mathrm{CO}_{2}$ humidified atmosphere, without phenol red, to avoid undesired photosensitising effects. The cells were then exposed for $90 \mathrm{~s}$ to an innovative green light-emitting diode (LED), DPL 305 (QTL Inc., Atlanta, GA, USA), emitting at $530 \pm 15 \mathrm{~nm}$, in order to obtain $1.6 \mathrm{~J} / \mathrm{cm}^{2}$ as the total light dose. The cells were then rinsed twice with 0.2 M PBS ( $\mathrm{pH} 7.4$ ), transferred to drug-free complete medium and allowed to recover for different time periods (from 0 to $72 \mathrm{~h}$ ).

Cytochrome $c$. Quantitative determination of cytochrome $c$ was performed by Assay Designs' human Cytochrome $c$ TiterZyme Enzyme Immunometric Assay (EIA) (Assay Designs Inc., Ann Arbor, MI, USA). Treated cells at various time points after PDT were rinsed twice with $0.2 \mathrm{M} \mathrm{PBS}(\mathrm{pH} 7.4)$ and resuspended in a digitonin cell permeabilization buffer $(250 \mathrm{nM}$ sucrose, $137 \mathrm{mM} \mathrm{NaCl}, 70 \mathrm{mM} \mathrm{KCl}, 1.3 \mathrm{mM}$ $\mathrm{Na}_{2} \mathrm{HPO}_{4}, 1.4 \mathrm{mM} \mathrm{K}_{2} \mathrm{HPO}_{4}, 0.2 \mathrm{mg} / \mathrm{ml}$ digitonin and $0.1 \%$ hydorol-M) to obtain the cytosolic fraction of cytochrome $c$ and then in RIPA cell lysis buffer $(50 \mathrm{mM}$ Tris- $\mathrm{HCl}$ (pH 7.4), $150 \mathrm{mM} \mathrm{NaCl}, 1 \mathrm{mM}$ EDTA, 1 mM EGTA, 1\% Triton X-100, 1\% sodium deoxycholate and $0.1 \%$ SDS) to obtain the mitochondrial fraction of cytochrome $c$. Both fractions were incubated with a monoclonal antibody to cytochrome $c$ immobilised on a microtiter plate for $1 \mathrm{~h}$. Then sample in excess was washed out and a biotinylated monoclonal antibody to cytochrome $c$ was added. After $1 \mathrm{~h}$ of incubation, excess antibody was washed out and streptavidin conjugated to alkaline phosphatase was added for $30 \mathrm{~min}$, before the addition of the pNpp substrate for additional $45 \mathrm{~min}$. The colour generated by the reaction was read at $405 \mathrm{~nm}$, using the ETI-SYSTEM Fast Reader (Sorin Biomedica, Vicenza, Italy). The values were expressed as picogram of cytochrome $c$ in total protein in milligram. Protein concentration was measured by a Bio-Rad protein assay.

Immunoblot analysis. At established time points after PDT, HeLa cells were collected by trypsin/EDTA $0.25 \%$, washed in ice-cold PBS, suspended in lysis buffer (50 mM Tris- $\mathrm{HCl}(\mathrm{pH} 7.4), 10 \mathrm{mM}$ DTT and $1 \mathrm{mM}$ PMFS) and further centrifuged at $10000 \times g$ for $10 \mathrm{~min}$. In order to separate the cytosolic and membrane proteins, the samples were centrifuged at $36000 \times g$ for $1 \mathrm{~h}$. The sediment (membrane proteins) was removed and suspended in Tris-HCl (1 mM)-DTT (50 mM)-PMSF (1 mM). The proteins were de-lipidated by various passages in methanol/chloroform. The supernatant (cytoplasm proteins) was precipitated in acetone. Then, the proteins were suspended in sample buffer (0.0625 M Tris-HCl (pH 6.8), 10\% glycerol, 2\% SDS, $50 \mathrm{mM}$ DTT and $1 \mathrm{mM}$ PMFS) and solubilised in a boiling water bath for 5-6 min. Protein concentration was determined by Bio-Rad protein assay.

Proteins $(30 \mu \mathrm{g})$ were separated by $13 \%$ SDS-PAGE under reducing conditions, followed by western blotting. The membranes were blocked for $1 \mathrm{~h}$ in $25 \mathrm{mM}$ TBS $(\mathrm{pH} 8.3) / 3 \%$ BSA. The following monoclonal primary antibodies were incubated with the appropriate membranes: anti-caspase-3 antibody (diluted 1:200), 
anti-caspase-8 antibody (diluted $1: 200$ ), anti-caspase-9 antibody (diluted $1: 1000$ ), anti-caspase-12 antibody (diluted 1:200) (each from MBL, Woburn, MA, USA); anti-Bax antibody (diluted 1:2000), anti-Bcl-2 antibody (diluted 1:1000), anti-Bid antibody (diluted 1:3000) (Abcam Inc., Cambridge, MA, USA); anti-Hsp70 antibody (diluted 1:2000), anti elF2 $\alpha$ antibody (diluted 1:1000), anti phospho-elF2 $\alpha$ antibody (diluted 1: 1000) (Cell Signaling Technology Inc., Beverly, MA, USA); antiGRP78 antibody (diluted 1: 1000) (Santa Cruz Biotechnology Inc., Santa Cruz, CA, USA); anti-LC3B antibody (diluted 1:500) (MBL); and anti-actin antibody (diluted $1: 2000)$. Appropriate IgG biotin-conjugated secondary antibodies $(1: 2000)$ were incubated with the membranes for $2 \mathrm{~h}$. The membranes were incubated with ExtrAvidin peroxidase (diluted $1: 1500$ ) at $4{ }^{\circ} \mathrm{C}$ for $1 \mathrm{~h}$, and after extensive washing in $25 \mathrm{mM}$ TBS ( $\mathrm{pH} \mathrm{8.3),} \mathrm{the} \mathrm{membranes} \mathrm{were} \mathrm{incubated} \mathrm{with} \mathrm{a} \mathrm{DAB} \mathrm{solution} \mathrm{for}$ $20 \mathrm{~min}$ in the dark. A densitometric analysis was performed using a GS-700 Imaging Densitometer (Bio-Rad, Hercules, CA, USA).

Qualitative analysis of caspase activity. Qualitative analysis of caspase-3, caspase-8 and caspase-9 was performed using the FLICA Apoptosis Detection kit (Immunochemistry Technologies, LLC, Bloomington, MN, USA), based a fluorochrome inhibitor of caspases (FLICA). Twenty-four hours before PDT treatment, $1 \times 10^{5}$ HeLa cells were seeded on coverslips in six-multi-well plates. The cells were then treated with RBAc. At established time points after PDT, the cells were stained with $30 \times$ FLICA solution in culture medium (1:30 ratio). The cells were then counterstained with Hoechst and observed under a fluorescence microscope, Eclipse 80i (Nikon, Tokyo, Japan), using a band-pass filter (excitation $490 \mathrm{~nm}$, emission $520 \mathrm{~nm}$ ), to view the green fluorescence of caspase-positive cells and a UV filter (excitation $365 \mathrm{~nm}$, emission $480 \mathrm{~nm}$ ) to view Hoechst stain.

Transmission electron microscopy. The presence of autophagosome vacuoles in HeLa cells was investigated by TEM. Cells were fixed with $2.5 \%$ glutaraldehyde in cacodylate buffer $(\mathrm{pH} \mathrm{7.4)}$, for $1 \mathrm{~h}$ at freezing temperature and post-fixed with $1 \% \mathrm{OsO}_{4}$ in same buffer. The samples were then dehydrated, embedded in Spurr resin and examined with a Zeiss 910 transmission electron microscope operating at $80 \mathrm{kV}$.

Inhibition experiments. Caspase activation was inhibited by using specific inhibitor of caspase-9 (20 $\mu \mathrm{M}$ Z-LEHD-FMK; R\&D Systems, Minneapolis, MN, USA) and caspase-8 (20 $\mu \mathrm{M}$ Z-LETD-FMK; R\&D Systems); apoptosis was inhibited by using pan-caspase inhibitor ( $20 \mu \mathrm{M}$ Z-VAD-FMK; R\&D Systems); autophagy was inhibited by using 3-MA (10 mM; Sigma-Aldrich Chem. Co., St. Louis, MO, USA), and necrosis was inhibited by using Nec-1 ( $300 \mu \mathrm{M}$; Santa Cruz Biotechnology Inc). The cell death inhibitors were added alone and in the presence or absence of others inhibitors $30 \mathrm{~min}$ before photodynamic treatment, during RBAc treatment (1-h incubation) and after irradiation during recovery time periods $(1,2,4,8,12,18,24$, 48 and $72 \mathrm{~h}$ ), in a $5 \% \mathrm{CO}_{2}$ humidified atmosphere at $37^{\circ} \mathrm{C}$. Dead cells were evaluated by using the Annexin-V/propidium iodide (PI) and MDC staining.

Annexin-V/PI staining. Dead cells were detected by the Annexin-V-fluorescein isothiocyanate (FITC) Apoptosis Detection kit (Sigma, St. Louis, MO, USA). Cells were rinsed twice with $0.2 \mathrm{M}$ PBS $(\mathrm{pH} 7.4)$ and incubated for $10 \mathrm{~min}$ in complete culture medium containing $0.5 \mu \mathrm{g} / \mathrm{ml} \mathrm{FITC-conjugated} \mathrm{Annexin-V} \mathrm{and} 2 \mu \mathrm{g} / \mathrm{ml} \mathrm{PI}$. Dead cells were recognised with a fluorescence microscope Eclipse $80 i$ (Nikon) for their positivity to Annexin- $V$ that binds the phosphatidylserine residues translocated to the outer leaflet of the plasma membrane. Early apoptotic cells were stained only by Annexin-V-FITC, necrotic cells were simultaneously stained by PI and AnnexinV-FITC and living cells were not stained. Counts were performed on at least 20 randomly chosen microscopic fields $(\times 40)$ and at least 300 cells were analyzed.

MDC staining. HeLa cells were stained with $0.05 \mathrm{mM}$ MDC (Fluka Chemie, Buchs, Switzerland) in PBS after PDT treatment at room temperature (RT) for $10 \mathrm{~min}$. The cells were washed two times with PBS and immediately observed using the fluorescence microscope, Eclipse 80i (Nikon). Counts were performed on at least 20 randomly chosen microscopic fields $(\times 40)$ and at least 300 nuclei were analysed.

\section{Measurement of ROS generation and cell viability assay}

Nitrobluetetrazolium. ROS were monitored by using nitrobluetetrazolium (NBT) assay. After PDT treatment, performed in the presence and in the absence of vitamin $\mathrm{C}(10 \mu \mathrm{M}$; Bayer, Leverkusen, Germany), HeLa cells were incubated with $0.1 \mathrm{mg} / \mathrm{ml} \mathrm{NBT}$ in EMEM culture medium for $2 \mathrm{~h}$ at $37^{\circ} \mathrm{C}$. The cells were washed three times with methanol and ROS generation, directly associated to the amount of NBT-formazan salt produced, was determined by NBT dye reduction, and it can be determined spectrophotometrically (DU 640B; Beckman Coulter, Brea, $\mathrm{CA}, \mathrm{USA}$ ) at $630 \mathrm{~nm}$ after solubilisation of crystal in $1 \mathrm{ml}$ containing solution $\mathrm{KOH}$ (2 M)/dimethyl sulphoxide (DMSO) (460 $\mu \mathrm{l} \mathrm{KOH}$ and $540 \mu \mathrm{l} \mathrm{DMSO})$.

MTT. MTT (3-(4,5-dimethylthiazol-2-yl)-2,5-diphenyltetrasolium bromide) assay (98\%; Sigma-Aldrich) is a cytotoxicity method. Briefly, at fixed recovery time points following RBAc incubation and irradiation, cells were incubated with $1 \mathrm{mg} / \mathrm{ml} \mathrm{MTT} \mathrm{in}$ culture medium for $2 \mathrm{~h}$. After extensive washing in PBS, live cells were determined by MTT dye reduction. The amount of MTT-formazan produced is directly associated with cell vitality and it can be determined spectrophotometrically (DU 640 B; Beckman Coulter, Brea, CA, USA) at $570 \mathrm{~nm}$ after solubilisation of crystal in $1 \mathrm{ml}$ of DMSO.

Statistical analysis. Two-tailed Student's $t$-test was used to analyze differences between controls and treated samples. The data are presented as the mean value \pm S.D., and all tests were performed at the 0.05 significance level.

\section{Conflict of Interest}

The authors declare no conflict of interest.

1. Babilas $P$, Karrer $S$, Sidoroff $A$, Landthaler M, Szeimies RM. Photodynamic therapy in dermatology - an update. Photodermatol Photoimmunol Photomed 2005; 21: 142-149.

2. Calzavara-Pinton PG, Venturini M, Sala R. Photodynamic therapy: update 2006. Part 1: photochemistry and photobiology. J Eur Acad Dermatol Venereol 2007; 21: 293-302.

3. Oleinick NL, Morris RL, Belichenko I. The role of apoptosis in response to photodynamic therapy: what, where, why and how. Photochem Photobiol Sci 2002; 1: 1-21.

4. Hilf R. Mitochondria are targets of photodynamic therapy. J Bioenerg Biomembr 2007; 39: 85-89.

5. Kessel D, Luo Y, Mathieu P, Reiners JJ. Determinants of the apoptotic response to lysosomal photodamage. Photochem Photobiol 2000; 71: 196-200.

6. Piette J, Volanti C, Vantieghem A, Matroule JY, Habraken Y, Agostinis P. Cell death and growth arrest in response to photodynamic therapy with membrane-bound photosensitizers. Biochem Pharmacol 2003; 15: 1651-1659.

7. Buytaert $E$, Dewaele M, Agostinis P. Molecular effectors of multiple cell death pathways initiated by photodynamic therapy. Biochim Biophys Acta 2007; 1776: 86-107.

8. Plaetzer K, Kiesslich T, Oberdanner CB, Krammer B. Apoptosis following photodynamic tumor therapy: induction, mechanisms and detection. Curr Pharm Des 2005; 11 : 1151-1165.

9. Bottiroli G, Croce AC, Balzarini P, Locatelli D, Baglioni $P$, Lo Nostro $P$ et al. Enzyme-assisted cell photosensitization: a proposal for an efficient approach to tumor therapy and diagnosis. The Rose Bengal fluorogenic substrate. Photochem Photobiol 1997; 66: 374-383.

10. Croce AC, Supino R, Lanza KS, Locatelli D, Baglioni P, Bottiroli G. Photosensitizer accumulation in spontaneous multidrug resistant cells: a comparative study with rhodamine 123, Rose Bengal and photofrin. Photochem Photobiol Sci 2002; 1: 71-78.

11. Soldani C, Croce AC, Bottone MG, Fraschini A, Biggiogera M, Bottiroli $G$ et al. Apoptosis in tumor cells photosensitized with Rose Bengal acetate is induced by multiple organelle photodamage. Histochem Cell Biol 2007; 128: 485-495.

12. Panzarini E, Tenuzzo B, Palazzo F, Chionna A, Dini L. Apoptosis induction and mitochondria alteration in human HeLa tumor cells by photoproducts of Rose Bengal acetate. J Photochem Photobiol B 2006; 83: 39-47.

13. Panzarini E, Tenuzzo B, Dini L. Photodynamic therapy-induced apoptosis of HeLa cells. Ann NY Acad Sci 2009; 1171: 617-626.

14. Soldani C, Bottone MG, Croce AC, Fraschini A, Bottiroli G, Pellicciari C. The Golgi apparatus is a primary site of intracellular damage after photosensitization with Rose Bengal acetate. Eur J Histochem 2004; 48: 443-448.

15. Dini L, Inguscio V, Tenuzzo B, Panzarini E. Rose Bengal acetate photodynamic therapyinduced autophagy. Cancer Biol Ther 2010; 10: 1048-1055.

16. Kessel D, Oleinick NL. Initiation of autophagy by photodynamic therapy. Methods Enzymol 2009; 453: 1-16.

17. Zitvogel L, Kepp O, Senovilla L, Menger L, Chaput N, Kroemer G. Immunogenic tumor cell death for optimal anticancer therapy: the calreticulin exposure pathway. Clin Cancer Res 2010; 16: 3100-3104.

18. Kepp P, Tesniere A, Shlemmer F, Michaud M, Senovilla L, Zitvogel L et al. Immunogenic cell death modalities and their impact on cancer treatment. Apoptosis 2009; 14: 364-375.

19. Schmitz I, Kirchhoff S, Krammer PH. Regulation of death receptor-mediated apoptosis pathways. Int J Biochem Cell Biol 2000; 32: 1123-1136.

20. Green DR, Kroemer G. The pathophysiology of mitochondrial cell death. Science 2004; 305: 626-629. 
21. Shiraishi $H$, Okamoto $H$, Yoshimura A, Yoshida H. ER stress-induced apoptosis and caspase-12 activation occurs downstream of mitochondrial apoptosis involving Apaf-1. J Cell Sc 2006; 119: 3958-3966.

22. Burlacu A. Regulation of apoptosis by Bcl-2 family proteins. J Cell Mol Med 2003; 7 : 249-257.

23. Dewaele M, Maes $\mathrm{H}$. Agostinis $\mathrm{P}$ ROS-mediated mechanisms of autophagy stimulation and their relevance in cancer therapy. Autophagy 2010; 6: 838-854

24. Finkel T, Holbrook NJ. Oxidants, oxidative stress and the biology of ageing. Nature 2000; 408: 239-247.

25. Carthy CM, Granville DJ, Jiang H, Levy JG, Rudin CM, Thompson CB et al. Early release of mitochondrial cytochrome $\mathrm{c}$ and expression of mitochondrial epitope $7 \mathrm{~A} 6$ with a porphyrinderived photosensitizer: $\mathrm{Bcl}-2$ and $\mathrm{Bcl}-\mathrm{xL}$ overexpression do not prevent early mitochondrial events but still depress caspase activity. Lab Invest 1999; 79: 953-965.

26. Kim HR, Luo Y, Li G, Kessel D. Enhanced apoptotic response to photodynamic therapy after bcl-2 transfection. Cancer Res 1999; 59: 3429-3432.

27. Sun $L$, Chen $T$, Wang $X$, Chen $Y$, Wei $X$. Bufalin induces reactive oxygen species dependent Bax translocation and apoptosis in ASTC-a-1 Cells. Evid Based Complement Alternat Med 2009; e-pub ahead of print 10 June 2009.

28. Granville DJ, Shaw JR, Leong S, Carthy CM, Margaron P, Hunt DW et al. Release of cytochrome c, Bax migration, Bid cleavage, and activation of caspases 2, 3, 6, 7, 8, and 9 during endothelial cell apoptosis. Am J Pathol 1999; 155: 1021-1025.

29. Granville DJ, Cassidy BA, Ruehlmann DO, Choy JC, Brenner C, Kroemer G et al. Mitochondrial release of apoptosis-inducing factor and cytochrome $\mathrm{c}$ during smooth muscle cell apoptosis. Am J Pathol 2001; 159: 305-311.

30. Kessel D, Castelli M. Evidence that bcl-2 is the target of three photosensitizers that induce a rapid apoptotic response. Photochem Photobiol 2001; 74: 318-322.

31. Cirman T, Oresić K, Mazovec GD, Turk V, Reed JC, Myers RM et al. Selective disruption of lysosomes in HeLa cells triggers apoptosis mediated by cleavage of Bid by multiple papain-like lysosomal cathepsins. J Biol Chem 2004; 279: 3578-3587.
32. Bottone MG, Soldani C, Fraschini A, Croce AC, Bottiroli G, Camboni T et al. Enzymeassisted photosensitization activates different apoptotic pathways in Rose Bengal acetate treated HeLa cells. Histochem Cell Biol 2009; 131: 391-399.

33. Verfaillie T, Salazar M, Velasco G, Agostinis P. Linking ER stress to autophagy: potential implications for cancer therapy. Int J Cell Biol 2010; e-pub ahead of print 17 January 2010.

34. Apel A, Herr I, Schwarz H, Rodemann HP, Mayer A. Blocked autophagy sensitizes resistant carcinoma cells to radiation therapy. Cancer Res 2008; 68: 1485-1494.

35. Ogata M, Hino S, Saito A, Morikawa K, Kondo S, Kanemoto S et al. Autophagy is activated for cell survival after endoplasmic reticulum stress. Mol Cell Biol 2006; 26: 9220-9231.

36. Demaurex N, Distelhorst C. Cell biology. Apoptosis - the calcium connection. Science 2003; 300: 65-67.

37. Tsai YC, Weissman AM. The unfolded protein response, degradation from endoplasmic reticulum and cancer. Genes Cancer 2010; 1: 764-778.

38. Zhuang S, Kochevar IE. Ultraviolet A radiation induces rapid apoptosis of human leukemia cells by Fas ligand-independent activation of the Fas death pathways. Photochem Photobiol 2003; 78: 61-67.

39. Saleh A, Srinivasula SM, Balkir L, Robbins PD, Alnemri ES. Negative regulation of the Apaf-1 apoptosome by Hsp70. Nat Cell Biol 2000; 2: 476-483.

40. Coupienne I, Bontems S, Dewaele M, Rubio N, Habraken Y, Fulda S et al. NF-kappaB inhibition improves the sensitivity of human glioblastoma cells to 5 -aminolevulinic acidbased photodynamic therapy. Biochem Pharmacol 2011; 81: 606-616.

Cell Death and Disease is an open-access journal published by Nature Publishing Group. This work is licensed under the Creative Commons Attribution-Noncommercial-No Derivative Works 3.0 Unported License. To view a copy of this license, visit http://creativecommons.org/licenses/by-nc-nd/3.0/ 